\title{
On the Characteristics and Translation of Business Texts
}

\author{
Wang Zheng \\ Xiamen Univeristy, Tan Kah Kee College
}

\author{
Keywords: Nature; Characteristics; Business Texts
}

\begin{abstract}
Ever since we entered the age of economic globalization, we have witnessed incredible changes brought about by the rapid development of business cooperation. As the most useful pragmatic text, business text plays an even more important role in this era of business globalization. It is against this background that the author of this thesis explores the nature and characteristics of business texts. In addition, a large number of sample translations of different types of business texts, e.g. business letter, business documents, etc. have been collected as data for discussions of the features and characteristics of typical business texts. Finally, this thesis introduces a number of commonly used business texts which better helps the readers to understand the nature and characteristics of business English and sheds light on further development of business English and its application to more varieties of translation studies.
\end{abstract}

\section{Significance of Business Texts}

We are living in an epoch in which economy and business are developing rapidly. Business is playing an increasingly important part in the economic development and business prosperity of all nations. In this age of economic globalization, business texts are pervasive in our society. They are used in almost every field of business cooperation and in every aspect of our life. Business texts are in fact becoming the most commonly and most important used texts. Translation of business texts, as a means to bridge cultural and information gaps between nations, has been playing a very important role in promoting global economic and business development, and China in particular benefits a great deal from the translation of business texts.

Generally speaking, the language of informative texts is characterized by conciseness, accuracy, objectiveness, practicality, briefness and courtesy. It is therefore imperative that translators of business texts retain these characteristics when they reproduce them in the target language.

Yet, not many Chinese translation theorists have paid attention to the special characteristics of business texts mentioned above. Therefore, it is safe to say that the study of business text translation is far from satisfactory, and the traditional theories seem incapable of guiding translators of business texts, which means more research is needed for guiding this type of translation.

As a form of informative texts, business texts aim at making certain facts clear and information passed through. Guided by this Skopos, this form of texts in most cases adopts domestication its common translation method. We may find that if the main purpose of foreignization is to preserve the foreign flavor of the text, then this purpose may not be important at all in business translation. In most cases, business texts have their fixed forms, and the conveyance of business information is required to be done in a very limited period of time (otherwise it may become obsolete.). Translators are not criticized for the beauty of the language they use, but may run into trouble at a single mistake occurring in meaning, which might result in great loss. Therefore, in business English translation, domestication prevails over foreignization although there are cases, when for the preciseness of language, the translator may adopt foreignization to copy the form of the source text sentence, or for better accuracy, coining a new word. Let's see some of the features of business language:

\section{The Characteristics of Business Texts}

As an important form of pragmatic texts, business texts aim at making certain facts clear and information passed through. In most cases, business texts have their fixed forms, courtesy style and 
the conveyance of business information is required to be done in a very limited period of time. Let's see some of the features of business language:

Lexical Features. As one part of English, most words of business English take the general characteristics of English lexis. Except some words, such as some price terms stipulated by international organizations, most of words are just common ones in English. Business English is much less ambiguous than literary English: and even daily English, and therefore it is much easier to find equivalence for business English in the target language. Most of words used in business English correspondingly have limited meanings and could be understood easily and clearly. However, words in business English still have their own features.

Frequent Use of Special Words and Terms. Special terms: They have their own special meanings in business English, which are unique and important in translating business language

\begin{tabular}{|l|l|l|l|}
\hline special terms & business meaning & special terms & business meaning \\
\hline proforma invoice & 形式发票 & irrevocable letter of credit & 不可撤销信用证 \\
\hline clearance sale & 清仓销价销售 & counter-offer & 还盘 \\
\hline premium & 保险费 & underwriter & 保险人 \\
\hline insurance policy & 保险单 & trimming charges & 平仓费 \\
\hline bid & 递盘 & surcharges & 附加费 \\
\hline more or less & 溢短装 & “bottleneck” restrictions & 瓶颈制约 \\
\hline
\end{tabular}

Common terms: These terms have a widest range of application in business English. They are used in both business language and ordinary language. But they have different meanings:

\begin{tabular}{|c|c|c|}
\hline word & business meaning & common meaning \\
\hline document & 单证、单据 & 文件 \\
\hline offer & 报盘、发价 & 提供 \\
\hline security & 担保、抵押品、保证金 & 安全 \\
\hline interest & 利息 & 爱好、兴趣 \\
\hline
\end{tabular}

Frequent Use of Abbreviations. Especially in written documents and letters, using abbreviated words is another distinctive feature of business English.

\begin{tabular}{|l|l|l|}
\hline acronyms & full name & meaning \\
\hline WTO & World Trade Organization & 世界贸易组织 \\
\hline ICC & International Chamber of Commerce & 国际商会 \\
\hline IMF & International Monetary Fund & 国际货币基金组织 \\
\hline D/P & Document against Payment & 付款交单 \\
\hline FAS & Free alongside Ship & 船边交货 \\
\hline GSP & General System of Preferences & 普惠制 \\
\hline CIF & Cost, Insurance\&Freight & 成本, 保险加运费价 \\
\hline
\end{tabular}

Syntactical Features. Frequent use of declarative sentences and prominence of long sentences are also the two syntactical features of business language.

SL: Sol a agent (or exclusive agent): A sole agent may also be a firm or a person (1) who acts exclusively for one foreign principal (2)with sole or exclusive agency rights (3) to sell (4)on- a commission basis (5)certain commodities (6)in a certain districts (7)under some kind of agreement or contract.

$\mathrm{TL}:$ 独家代理:独家代理也一样可以是一家公司或个人。根据某种协议或合同, 享有独家代 理权, 以佣金作基础, 在某一特定地区推销外国委托人的某些特定商品。(Liao Ying, 2004:261)

In this example, the main structure is "a sole agent may also be a firm or a person". When the original sentence is translated, the former sequence is adjusted as(7)(2)(4)(6)(3)(1)(5), to keep the TL logical and legible. It is also obvious that this sentence is a declarative sentence.

As the two features have been discussed in the last section, this paper will not focus on the discussion of these two features. Instead, the following part will focus on analyzing the textual 
features of business language, which is considered the most important factor in translating this special field.

Textual Features. When analyzed at textual level, business English has the following features.

Settled Format. Textual feature is always reflected by lexical and syntactic aspects. Generally, in business English, a text is often made up of by several settled parts which are related to the key issue closely. Take business letter as example. In most business letters, the first part is the introduction.

In this part, the purpose of writing the letter or the issue with mutual concerns is mentioned.

For example:

On opening:

We refer to your order No 7 and regret to say that... 兹谈及你方 7 号订单事宜，遗憾告知....

In answer to your letter of... 兹复你们......的来信

We are pleased to inform you that... 我们很高兴告知你们...

We have received your letter of. 二我们已收到你们......的来信。

We acknowledge receipt of your letter of ... 感谢你方来信询问......

The last part is about the ending and complementary close.

On ending:

Looking forward to your early reply!

Yours faithfully,

Please reply immediately! 即复为盼!

Yours faithfully,

Your early reply will be highly appreciated! 您若能尽早回复将不胜感激!

Yours sincerely,

Awaiting your immediate reply. 请即复。

Yours sincerely, (Zhang Xinhong, Liming, 2003)

These are the most frequently used openings and endings. What follow these sentences are the details of the issue, which is the core of the letter and is always stated clearly and concisely. And if concerned several issues, these issues would be presented with primary and secondary orders.

For example: frequent-used sentences for establishing trade relation.

a. 我们愿与贵公司建立商务关系。

We are willing to establish trade relations with your company.

b. 我们希望与您建立业务往来。

Please allow us to express our hope of opening an account with you.

c. 我公司经营电子产品的进出口业务, 希望与贵方建立商务关系。

This corporation is specialized in handing the import and exports business in electronic products and wishes to enter into business relations with you.

For quotation:

a. 兹函请提供......的报价。

We are writing to invite quotations for the supply of....

b. 请将定期供应.......之报价赐知。

Please let us have a quotation for the regular supply for....

c. 请将下列货品的最低价格赐知。

Kindly quote us your lowest prices for the goods listed below.

For inquiry:

a. 随函寄上询价单一份。

We are enclosing here with an inquiry sheet.

b. 如果贵方对......感兴趣, 请告具体询价。

If you are interested in our...,please let us know with a specific inquiry.

c. 一收到贵方具体询价单，我方马上航空邮上样品册并报价。

Quotations and sample books will be airmailed to you upon receipt of your specific inquiry. 
Formal and Courtesy Style. Courtesy and tactful manner of speaking are very important in business letters. Courtesy is an important language feature of international business letters. A letter expressed courteously can set up a good and honest image in the eyes of the readers who will be glad to cooperate with you and serve you wholeheartedly. If we want to express our regrets or complaints, if we can not meet the requirements or conditions from our counterpart, or if we want to put forward our suggestions, hopes or requests, we need to voice politely and tactfully, otherwise we may irritate our partner and lose the business. Please compare the following sentences in each group:

※We have not received your payment of the balance of US \$5 000 .

We regret having to remind you that we have not received your payment of the balance of US \$5 000 .

※You have to replace the damaged records.

We will appreciate it if you replace the damaged records.

※Your letter is not clear at all, I cannot understand it.

If I understood your letter correctly, I would immediately accept your offer. (Zhang Xinhong, 2003:173)

In the examples above, the second sentence in each group sounds much more polite and tactful and reflects the feature of manner of speaking in international business letters. While the first sentence in each group is expressed so directly as to appear a little rudeness, which should be avoided in business letters. In Business English letters, when we are making an explanation, we are explaining with joy, willingness, thanks or regret to show our sincerity, politeness or consideration. More examples are as follows:

ST: Thank you for your letter of June 6 and we enclose our OrderNo.2245 for ladies'shoes.

TT: 感谢贵方 6 月 6 日来信，现寄上第 2245 号女鞋订单。(Zhang Xinhong, 2003:174)

ST: With reference to your letter of May6,we are pleased to give an order for the following.

TT:根据贵方 5 月 6 日来函，我方乐意订购下列货物。(Zhang Xinhong, 2003:174)

ST: In reply to your enquiry of May12,we regret to tell you that our cotton sweaters do not come in any size larger than 18.

贵方 5 月 12 日来函询问之事，我们很遗憾地奉告，我们的全棉运动服最大的为 18 号。 (Zhang Xinhong, 2003:174)

In many cases, people who use business English are from different countries, therefore, business English is very formal to adapt to this situation. Besides, to achieve high efficiency, politeness in business English is also significant. What do these two points reflect in the text of business English is a large amount of formal and courtesy words are used in the whole text:

We should be grateful if...如蒙......., 我们当很感谢......

We ensure you of our best services at all times.我们尽我们所能为您服务.

Thank you for your letter dated...谢谢你方于....日的来信

Your favorable information will be appreciated.恭候佳音!

Your early reply will be highly appreciated.如蒙早复, 不胜感激!

ST: We should be greatly obliged if you would inform us what you know about their business integrity, their ability to meet their obligations, or any pertinent matters that you think would be informative to us.

如蒙能告知有关对方商业信誉和他们履行义务的能力或任何对我方有帮助的相关事宜, 我 方不胜感激! (Feng Xiangchun, 2003:)

ST: It goes without saying that any information you may obtain for us will be treated as strictly confidential and you are free from any responsibility:

TT:不用说，我们一定不会泄露您提供的任何信息，您也不需要承担任何责任。

The letter is particularly formal with very polite tone. Such words as "oblige”, "integrity”, "pertinent", "confidential" show it is with formal and polite style. And no word could be found which has no relationship with the key issue. 


\section{Translation of Business Texts}

Business texts aim at making certain facts clear and information passed through. (Nord, 1997:37). Guided by this Skopos, this form of texts in most cases adopts domestication its common translation method. We may find that if the main purpose of foreignization is to preserve the foreign flavor of the text, then this purpose may not be important at all in business translation. In most cases, business texts have their fixed forms, and the conveyance of business information is required to be done in a very limited period of time (otherwise it may become obsolete.). Translators are not criticized for the beauty of the language they use, but may run into trouble at a single mistake occurring in meaning, which might result in great loss. Therefore, in business English translation, domestication prevails over foreignization although there are cases, when for the preciseness of language, the translator may adopt foreignization to copy the form of the source text sentence, or for better accuracy, coining a new word.

\section{Conclusion}

In all, business text is relatively formal, standard and polite. Most business texts have settled formats. And the entire text is very compact and has good cohesion and coherence. Only bearing these characteristics into mind can translators of business English do their jobs efficiently.

In addition, for the limited pages in the thesis, the author cannot present all the characteristics of business texts and translation strategies to business texts in details. Those who show interest in pragmatic translation studies can refer to a variety of business texts and make more translation practice to probe into more effective strategies and approaches to pragmatic business translation.

\section{Reference}

[1] Che Lijuan, Jia Xiuhai. A Course for Business English Translation [M]. Beijing: University of International Business and Economics Press, 2007.

[2] Feng Xiangchun. English for International Business Communication [M]. Beijing: University of International Business and Economics Press, 2003.

[3] Liao Ying. English for International Business Negotiations [M]. Beijing: University of International Business and Economics Press, 2004.

[4] Zhang Xinhong, Li Ming. Business English Translation [M]. Beijing: Higher Education Press, 2003.

[5] Nord, C. Translating as a Purposeful Activity—Functional Approaches Explained [M]. Shanghai: Shanghai Foreign Language Education Press, 1997. 